\title{
Interpersonal Values of Athletic and Non - Athletic Students of University of Chittagong
}

\author{
Lisa Paul ${ }^{1 *}$, Md. Nurul Islam², Muhammad Alamgir Hossain ${ }^{3}$
}

\section{ABSTRACT}

The present study investigated the interpersonal values of athletic and non - athletic students of university of Chittagong. To accomplish this purpose, a total of 80 students (20 athletic male, 20 athletic female, 20 non - athletic male, and 20 non - athletic female) were selected purposively as the sample of the study. The Bangla version of interpersonal values scale was used to collect data. Results showed that values regarding support, recognition, and benevolence varied significantly as a function of gender. Male was found to be more benevolent but less supportive and recognizable than female. Athletic and non - athletic students differ significantly in conformity and benevolence. Athletic students obtained higher scores both on conformity and benevolence than non - athletic students.

Keywords: Interpersonal Values, Athletes, None - Athletes, Male, Female, Comparison.

Values are considered as comparatively stable beliefs which are developed through acquiring different attitudes. Damon (2004) define Values are fundamental aspects of personality which have a certain influence on a person's life, and adolescence is indispensable for their development. According to Rokeach $(1968 \mathrm{a}, \mathrm{b})$ values, attitudes, and behaviors are formed within an organization of beliefs that pivots on the center of the social human being. In interpersonal relationships values play a vital role such as support, conformity, recognition, independence, benevolence, and leadership color one's perception of people around him and affect the way of interacting with them. Values are accumulated in the family and educational surroundings. Family gives the first and foremost experience for initial development of the individual's identity and helps to acquire a primary value system (Fuentes, García, Gracia, \& Lila, 2011) while a person can interact with others and form a hierarchical classification of values in education settings (Jiménez, Moreno, Murgui, \& Musitu, 2008). Ros, Grad and Martínez-Sánchez (1996) found benevolence was favorably correlated with study behaviors, a little like conformity, which indicated the highest associations with all study habits.

\footnotetext{
${ }^{1}$ Lecturer, Department of Psychology, University of Chittagong, Chittagong, Bangladesh

${ }^{2}$ Assistant Professor, Department of Psychology, University of Chittagong, Chittagong, Bangladesh

${ }^{3}$ Lecturer, Department of Psychology, University of Chittagong, Chittagong, Bangladesh

*Responding Author

(c) 2016 I L Paul, N Islam, M Hossain; licensee IJIP. This is an Open Access Research distributed under the terms of the Creative Commons Attribution License (http://creativecommons.org/licenses/by/2.0), which permits unrestricted use, distribution, and reproduction in any Medium, provided the original work is properly cited.
} 
Attitudes are closely related with interpersonal values, e.g., people who are the sufferer of various assaults might shape a negative perception and values about their situations, perceive it as risky and perilous (Sutton \& Smith, 1999), which also makes the person fearful (Polo, León, Gómez, Palacios, \& Fajardo, 2013), introverted (Oñate \& Piñuel, 2005), socially disintegrated (Moreno, Vacas, \& Roa, 2006), etc. Castaño \& León del Barco (2010) did a study with 162 university students demonstrated that participants who treated themselves as extroverted and sociable generated more use of personal techniques for meeting with other students to whom they could tell their problems and complications, although those who considered themselves as introverted showed strategies that distanced them from meet with others. Several studies have revealed the association of values, attitudes, social - cognitive techniques and different ways in which these are interrelated. Enciso and Lozano (2011) conducted a research study with young participants aged from $11-18$ years old having a group who were in volunteer programs and another group who were not, they found that volunteer group showed greater conformity with socially appropriate, altruistic, collaborative, and prosocial leadership behavior.

Interpersonal values have provoked the consideration of research in the social science (Pertegal, Oliva, \& Hernando, 2010), where they are evaluated for the activities they accomplish in decision making (Wallace, Pettit, Scheffler, \& Smith, 2006), avoiding destructive behavior (Benson, Scales, Hamilton, \& Sesman, 2006), and determine what values make a person socially skilled (Oliva et al., 2010). Values have been evident to affect political affiliations (e.g., Schwartz, 1992); life style options (e.g, Kahle, Beatty, \& Homer, 1986); organizational decision making (e.g., Korsgard, Meglino, \& Lester, 1996; Pant \& Lachman, 1998); consumer innovativeness (Steenkamp, ter Hofstede, \& Wedel ,1999), customer option of products (Allen \& Ng, 1999); physical functioning levels of college students (Engstrom, Philips, \& Francis, 1999); and advertising policy (Becker, 1999). Indeed, Rokeach and Ball - Rokeach (1989) acclaimed that values "are among the very few social psychological concepts that have been successfully employed across all social science disciplines” (p. 775). Meglino and Ravlin (1998) also indicated the effects of values on decisions, evaluations, affect, and perceptions.

Important competencies and qualities are flourished through participation in sports which are not achieved through the educational programs. Athletic participation helps to develop interpersonal skills, peer relationships, and leadership abilities (Astin, 1993; Ryan, 1989); students' personal and social well - being (Cantor \& Prentice, 1996); and students' commitment to their educational institutions (Astin, 1993). Recently, several studies have indicated the positive influence of sport and physical activities on psychological well - being and health (Hui, Chui, \& Woo, 2009; Leah, 2009; Quested \& Duda, 2009 ). Sports contribute to socialization in schools (Gerdy, 1992); teamwork, sportsmanship, and citizenship behaviors (Harper, 1986); leadership qualities and satisfaction with the college experiences (Hood, Craig, \& Ferguson, 1992). Athletic participation develops educational aspirations, selfconcept, and GPAs (Soltz, 1986). Athletics also develops students' sense of belonging or status within society and the educational environment (Goldberg \& Chandler, 1992). It helps to develop personal and moral character 
while raising leadership, cooperation, coping strategies, risk taking, and achievement skills (Thompson, 1986). Dobosz \& Beaty (1999) in their study indicated that athletes showed higher leadership ability than non - athletes. In another study it was found that athletes were significantly more politically conservative than non - athletes in senior year and males reported being significantly more politically conservative than females (Aries, McCarthy, Salovey, \& Banaji, 2004). Boulze, Launay, \& Nalpas (2016) did a study on 137 subjects and found significant differences between males and females on conformity, recognition, benevolence, and leadership scores. They found males significantly obtained higher scores on conformity and benevolence than females, whereas the opposite results were found for recognition and leadership.

\section{OBJECTIVES:}

The present study includes the following objectives.

1. To compare interpersonal values between male and female students.

2. To examine comparison of interpersonal values between athletic and non - athletic students.

\section{METHOD}

\section{Participants}

The present study comprised of 80 students of them 40 athletes and 40 non - athletes. The age range of the participants was from 18 to 25 years. In order to collect data, non random sampling techniques were used. Athletic students were selected purposively with the help of department of physical education of university of Chittagong. On the other hand, non - athletic students were chosen purposively from various department of the mentioned university. The following table shows the sample distribution of the present study.

Table 1, Frequency and percentage of students

\begin{tabular}{|l|l|l|l|}
\hline Participants & Gender & $\boldsymbol{N}$ & \% \\
\hline Athletes & Male & 20 & 25 \\
\hline & Female & 20 & 25 \\
\hline Non - Athletes & Male & 20 & 25 \\
\hline & Female & 20 & 25 \\
\hline Total & & $\mathbf{8 0}$ & $\mathbf{1 0 0}$ \\
\hline
\end{tabular}

\section{Instruments}

The Bangla version of original interpersonal values scale of Gordon (1960) was adapted by Begum and Khanam (1983). At first the English version of the scale was administered on a 
sample. Then after three days Bangla version of this scale was administered on the same sample. High correlation was found between the responses of the two different versions. Table 2 shows the correlation between the two versions of interpersonal values scale.

Table 2, Correlation between the Two Versions of Interpersonal Values Scales

\begin{tabular}{|l|l|}
\hline Values & $\boldsymbol{r}$ \\
\hline Support & 0.76 \\
\hline Conformity & 0.91 \\
\hline Recognition & 0.78 \\
\hline Independence & 0.73 \\
\hline Benevolence & 0.82 \\
\hline Leadership & 0.99 \\
\hline
\end{tabular}

The scale consists of 90 statements altogether. How to respond to this statement is stated elaborately in the instruction. Each value contains the following numbers of statements.

a) Support (S) contains 15 statements.

b) Conformity (C) contains 14 statements.

c) Recognition (R) contains 13 statements.

d) Independence (I) contains 16 statements.

e) Benevolence (B) contains 16 statements.

f) Leadership (L) contains 16 statements.

\section{Scoring}

The participants select each item by putting $(\sqrt{ })$ mark. For the most preferable statement 2 score is given and for the least preferable statement 0 is given where 1 is given for no $(\sqrt{ })$ mark. The scoring system is quite different and difficult. Attention is strongly required for collection the accurate data; otherwise there may be a chance to miss data. First, one has to count the scores for each of the six values. Then to ensure whether the calculation is right or wrong, one has to sum the scores of the six values that should result as 90. However, if the total score emerge in between 85 to 95 or if more than two errors emerge, then that result may also be taken into account. In this regard, it will be counted as standard error.

In this experiment, the explanation is given by the score of the subject obtained from the statements. But explanation is given only for the high score and there is no alternative explanation for the low scorers. To achieve low score means the subject has least value or no 
value for that particular value level. The norm that used here is not widely verified, so any kind of specific prediction should not be done.

\section{Reliability and Validity}

Strong evidences are found for the high level of reliability and validity. A test was administered twice in 10 days interval on 79 students and by 'test - retest' system the scores were verified and the reliability was measured. In another test 'Kuder - Richardson test' was used and got the same result for reliability. The outcomes for reliability obtained from these two tests are given below in table 3.

\section{Table 3, Reliability and Validity of Scale}

\begin{tabular}{|l|l|l|l|l|l|l|}
\hline Tests & Support & Conformity & Recognition & Independence & Benevolence & Leadership \\
\hline Test-retest & 0.83 & 0.86 & 0.78 & 0.89 & 0.83 & 0.88 \\
\hline $\begin{array}{l}\text { Kuder- } \\
\text { Richardson }\end{array}$ & 0.76 & 0.82 & 0.79 & 0.86 & 0.86 & 0.83 \\
\hline
\end{tabular}

\section{Procedure}

The purpose of the present study was clearly explained to the participants. They were also assured about the confidentiality of information provided by them. After verbal instruction the questionnaire was administered to each of the 80 respondents individually. The participants were requested to reflect their actual feelings regarding to each question. They chose two statements out of three. One is most preferable and another is least preferable and the remaining statement keeps blank in every questions. After completion of the questionnaire the respondents were thanked for co - operation.

\section{RESULTS}

\section{Table 4, Mean Differences of Interpersonal Values by Gender}

\begin{tabular}{|c|c|c|c|c|c|c|c|c|}
\hline 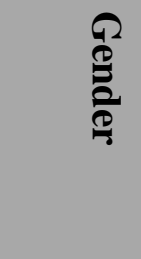 & & 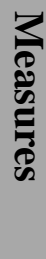 & 占 & 串 & 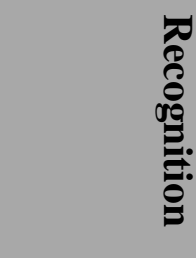 & 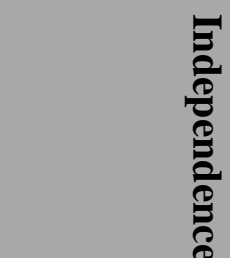 & 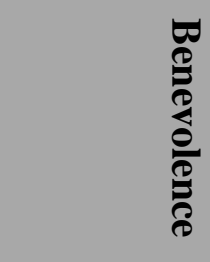 & 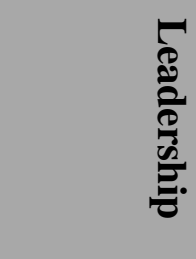 \\
\hline Male & $M$ & & 13.05 & 15.90 & 10.50 & 17.30 & 19.65 & 13.60 \\
\hline & $S D$ & & 2.66 & 3.90 & 3.56 & 4.85 & 4.57 & 3.98 \\
\hline Female & $M$ & & 16.42 & 14.75 & 13.02 & 16.50 & 15.75 & 13.55 \\
\hline & $S D$ & & 3.19 & 3.47 & 4.01 & 4.28 & 4.55 & 5.14 \\
\hline
\end{tabular}


According to table 4, female significantly obtained higher score in support $(M=16.42)$ and recognition $(M=13.02)$. On the other hand, male significantly obtained higher scores in benevolence $(M=19.65)$.

Table 5, Mean Differences of Interpersonal Values by Types of Students

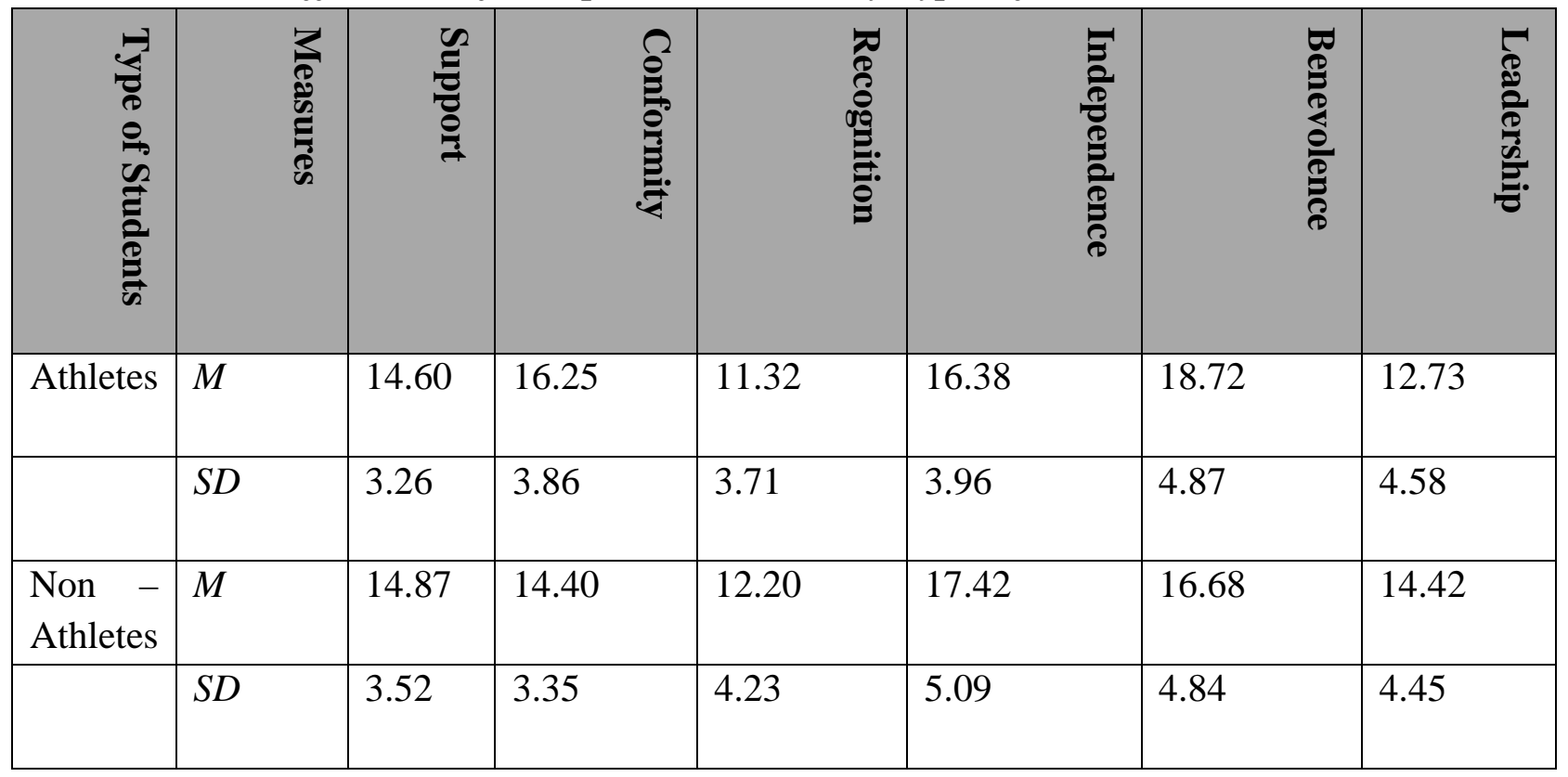

The above table confirm that athletic students significantly obtained higher scores in conformity $(M=16.25)$ benevolence $(M=18.67)$.

Table 6, Test of Between Subject Effects on Support

\begin{tabular}{|l|l|l|l|l|}
\hline Source & SS & Df & MS & F \\
\hline Gender & 227.812 & 1 & 227.812 & 25.932 \\
\hline Type of students & 1.512 & 1 & 1.512 & 0.172 \\
\hline $\begin{array}{l}\text { Gender type of } \\
\text { students }\end{array}$ & 4.512 & 1 & 4.512 & 0.514 \\
\hline Error & 667.650 & 76 & 8.785 & \\
\hline
\end{tabular}

Table 6 shows that gender had significant effect on support $[F(1,76)=25.932, p<.001]$. 
Table 7, Test of Between Subject Effects on Conformity

\begin{tabular}{|l|l|l|l|l|}
\hline Source & SS & $d f$ & MS & F \\
\hline Gender & 26.450 & 1 & 26.450 & 2.033 \\
\hline Type of students & 68.450 & 1 & 68.450 & 5.262 \\
\hline $\begin{array}{l}\text { Gender } \\
\text { students type of }\end{array}$ & 6.050 & 1 & 6.050 & 0.465 \\
\hline Error & 988.600 & 76 & 13.008 & \\
\hline
\end{tabular}

Table 7 reveals that type of students has significant effect on conformity [ $F(1,76)=5.262, p<$ $.05]$.

Table 8, Test of Between Subject Effects on Recognition

\begin{tabular}{|l|l|l|l|l|}
\hline Source & SS & df & MS & F \\
\hline Gender & 127.512 & 1 & 127.512 & 8.845 \\
\hline Type of students & 15.312 & 1 & 15.312 & 1.062 \\
\hline $\begin{array}{l}\text { Gender } \\
\text { students type of }\end{array}$ & 12.013 & 1 & 12.013 & 0.833 \\
\hline Error & 1095.650 & 76 & 14.416 & \\
\hline
\end{tabular}

Table 8 indicates that gender had significant effect on recognition $[F(1,76)=8.845, p<.01]$.

Table 9, Test of Between Subject Effects on Independence

\begin{tabular}{|l|l|l|l|l|}
\hline Source & SS & $\boldsymbol{d f}$ & MS & F \\
\hline Gender & 12.800 & 1 & 12.800 & 0.617 \\
\hline Type of students & 22.050 & 1 & 22.050 & 1.062 \\
\hline $\begin{array}{l}\text { Gender } \\
\text { students type of }\end{array}$ & 36.450 & 1 & 36.450 & 1.756 \\
\hline Error & 1577.900 & 76 & 20.762 & \\
\hline
\end{tabular}


No significant effects were found for the independent variables and their interaction on independence.

Table 10, Test of Between Subject Effects on Benevolence

\begin{tabular}{|l|l|l|l|l|}
\hline Source & SS & df & MS & F \\
\hline Gender & 304.200 & 1 & 304.200 & 15.011 \\
\hline Type of students & 84.050 & 1 & 84.050 & 4.148 \\
\hline $\begin{array}{l}\text { Gender } \\
\text { students type of }\end{array}$ & 0.450 & 1 & 0.450 & 0.022 \\
\hline Error & 1540.100 & 76 & 20.264 & \\
\hline
\end{tabular}

Table 10 shows that gender $[F(1,76)=15.011, p<.001]$ and type of students $[F(1,76)=$ 4.148, $p<.05$ ] had significant effects on Benevolence.

Table 11, Test of Between Subject Effects on Leadership

\begin{tabular}{|l|l|l|l|l|}
\hline Source & SS & df & MS & F \\
\hline Gender & 0.050 & 1 & 0.050 & 0.002 \\
\hline Type of students & 57.800 & 1 & 57.800 & 2.759 \\
\hline $\begin{array}{l}\text { Gender } \\
\text { students type of }\end{array}$ & 1.800 & 1 & 1.800 & 0.086 \\
\hline Error & 1591.900 & 76 & 20.946 & \\
\hline
\end{tabular}

No significant effects were found for the independent variables and their interaction on leadership.

\section{DISCUSSION}

The present study was conducted to investigate the interpersonal values of athletic and non athletic students. The study attempts to measure differences in interpersonal values as a function of gender and type of students. It was assumed that as the athletic and non - athletic students belong to different environment and they get different facilities, there would have differences among them in their values. It was also assumed that because of different social rules and expectation female would differ from male students in interpersonal values. 
The findings of the present investigation revealed that three interpersonal values (support, recognition, and benevolence) were found to be different for male and female students out of six interpersonal values (e.g., support, conformity, recognition, independence, benevolence, and leadership). Results showed that female significantly got higher scores in support and recognition but lower scores in benevolence as compared to male students. Female scored higher scores in social support $(M=16.42)$ than males did $(M=13.05)$ which is expected regarding the social norms and cultural trends of Bangladesh. In the context of Bangladeshi culture, male gets more facilities and attention than female. Females are more restricted here and get less encouragement to explore their environment. As a result, females become more dependent for her emotional fulfillment which was reflected on their higher scores in support. It was also found that female significantly obtained more scores in recognition $(M=13.02)$ than males did $(M=$ 10.50). This result is consistent with prior research (Boulze, Launay, \& Nalpas, 2016). Having greater recognition means that females want to be more important, accepted, popular, and recognize by others. But females do not get enough opportunities to develop their proper skills in coping with stressors and they are not confident with their resources. So, they scored lower in benevolence $(M=15.75)$ than males did $(M=19.65)$ which is also consistent with previous study (Boulze, Launay, \& Nalpas, 2016). Males obtained higher scores on benevolence means that they helps other and try to do something better for other people, society, and country. In other interpersonal values such as conformity, independence, and leadership, male and female did not differ significantly. It indicates that stereotype ideas of male and female are changing with the spread of education. In modern society female are free to make their decisions independently and are able to do things in their own ways.

Results also evident that athletic students were significantly more benevolent $(M=18.72)$ than non - athletic students $(M=16.68)$. This result means that athletic students are motivated by team and get more opportunities and facilities to prepare themselves for complex and competitive role so that they can serve the nation. In addition, athletic students obtained significantly higher score $(M=16.25)$ on conformity than non - athletic students $(M=14.40)$. It indicates that athletic students are more interested in doing those activities which are socially accepted and conforming to social rules. But not - athletic students seem to refuse a life style which is not in accord with social conventions. Other interpersonal values, for instance, support, recognition, independence, and leadership are not significantly varied according to athletic and non - athletic status of students.

The study has few limitations. Firstly, the research study was conducted with a small number of participants $(\mathrm{n}=80)$. Then, the sample was chosen conveniently only from the University of Chittagong. It makes difficult to assure how much these findings can be generalized to the whole population of Bangladesh. After that, this study focused on the variation of interpersonal values among students without addressing the possibility that other variables might also influence this variable. Finally, the questionnaire was self - reported. It was, therefore, possible that many participants might not gave their accurate response. 


\section{REFERENCES}

Allen, M.W., \& Ng, S.H. (1999). The direct and indirect influence of human values on product ownership. Journal of Economic Psychology, 20, 5-39.

Aries, E., McCarthy, D., Salovey, P., \& Banaji, M. R. (2004). A comparison of athletes and nonathletes at highly selective colleges: Academic Performance and Personal Development. Research in Higher Education, Vol. 45, No. 6.

Astin, A. W. (1993). What Matters in College? Four Critical Years Revisited. San Francisco: Jossey-Bass.

Becker, B.W. (1999). Values in advertising research: A methodological caveat. Journal of Advertising Research, 38(4), 57-60.

Begum, H. A. \& Khanam, M. (1983). Interpersonal Values and Friendship. Paper read in the National Science Conference, Dhaka, Bangladesh.

Benson P. L., Scales P. C., Hamilton S. F., Sesman A. (2006). "Positive youth development: theory, research and applications," in Theoretical Models of Human Development. Handbook of Child Psychology, Vol. 1 ed. Lerner R. M., editor. (New York, NY: Wiley; ), 894-941.

Boulze, I., Launay, M., \& Nalpas, B. (2016). Variation of Interpersonal Values Following Alcohol Withdrawal in Alcoholics Seeking Treatment: 12-Month Longitudinal Study. Journal of Psychology, 7, 19-27.

Cantor, N. E., \& Prentice, D. A. (1996). The Life of the Modern-Day Student-Athlete: Opportunities Won and Lost. Paper presented at the Princeton Conference on Higher Education, Princeton University, Princeton, NJ.

Castaño E., \& León del Barco B. (2010). Estrategias de Afrontamiento del Estrés y Estilos de Conducta Interpersonal [Coping Strategies and Interpersonal Behavior Profiles]. Rev. Int. Psicol. Ter. Psicol. 10245-257.

Damon W. (2004). What is positive youth development? Am. Acad. Polit. Soc. Sci. 591, 13-24 $10.1177 / 0002716203260092$

Dobosz, R., \& Beaty, L. (1999 ).The relationship between athletic participation and high school student's leadership ability. Adolescence, 34, 215-20.

Enciso E., \& Lozano M. (2011). Diferencias en Actitudes y Estrategias Cognitivas Sociales en Jóvenes Vinculados and no Vinculados a Programas de Voluntariado [Differences in the Attitudes and the Cognitive Social Strategies Among Linked and not Linked Youths to Programs of Volunteer Service of Bogotá]. Psychol. Av. Discip. 5, 81-95.

Engstrom, L., Philips, A.D., \& Francis, R. (1999). The prediction of physical activity levels of college students based on personal values and perceived barriers. Research Quarterly for Exercise and Sport, 70, A26-A27.

Fuentes M. C., García J. F., Gracia E., \& Lila M. (2011). Autoconcepto and Ajuste Psicosocial en la Adolescencia [Self-Concept and Psychosocial Adjustment in Adolescence]. Psicothema, 23, 7 - 12.

Gerdy, J. R. (1992). Faculty and Collegiate Athletics Reform: Seizing the Moment. Educational Record, Summer 1992. 
Goldberg, A. D., and Chandler, T. J. L. (1992). Academics and Athletics in the Social World of Junior High School Students. The School Counselor, 40, 40-45.

Gordon, L. V. (1960). Survey of Interpersonal Values. Chicago: Science Research Associates.

Harper, T.(1986). Academic Eligibility Requirements for Student Athletes: Two Points of View. NASSP Bulletin, September 1986.

Hood, A. B., Craig, A. F., \& Ferguson, B. W. (1992). The Impact of Athletics, Part-time Employment, and Other Activities on Academic Achievement. Journal of College Student Development, 33, 447-53.

Hui, E. Chui, B. T. \& Woo, J. (2009). Effects of dance on physical and psychological well-being in older persons. Archives of Gerontology and Geriatrics, 49, 1, e45-e50.

Jiménez T., Moreno D., Murgui S., \& Musitu G. (2008). Factores Psicosociales Relacionados con el Status Social del Alumno en el aula: el rol de la Reputación Social, la Amistad, la Conducta Violenta y la Relación con el Profesor [Psychosocial Factors Associated with Social Status of Students in the Classroom: The Role of Social Reputation, Friendship, Violent Vehavior and the Relationship With the Teacher]. Rev. Int. Psicol. Ter. Psicol. 8, 227-236.

Kahle, L.R., Beatty, S.E., \& Homer, P. (1986). Alternative measurement approaches to consumer values: The List of Values (LOV) and Values and Life Style (VALS). Journal of Consumer Research, 13, 405-409.

Korsgard, M.A., Meglino, B.M., \& Lester, S.W. (1996). The effects of other-oriented values on decision making: A test of propositions of a theory of concern for others in organizations. Organizational Behavior and Human Decision Processes, 68, 234-245.

Leah, J. B. (2009). Health Enhancing Physical Activity and Eudemonic Well-being. Dean of the College of Kinesiology. University of Saskatchewan. S7N 5B2.

Meglino, B.M., \& Ravlin, E.C. (1998). Individual values in organizations: Concepts, controversies, and research. Journal of Management, 24, 351-389.

Moreno M., Vacas C., \& Roa J. M. (2006).Victimización Escolar y Clima Sociofamiliar [Victimization and school climate sociofamiliar]. Rev. Iberoam. Educ. 40, 12-17.

Oliva A., Ríos M., Antolín L., Parra A., Hernando A., \& Pertegal M. A. (2010). Más Allá del Déficit: Construyendo un Modelo de Desarrollo Positivo Adolescente [Beyond the Deficit: Building a Model of Positive Youth Development]. Infanc. Aprendiz. 33, 223234 10.1174/021037010791114562.

Oñate A., \& Piñuel I. (2005). Informe Cisneros VII: Violencia and acoso escolar en alumnos de Primaria, ESO and Bachiller [Cisneros Report VII: Violence and Bullying in Primary Pupils, ESO and Bachiller]. Madrid: Instituto de Innovación educativa and Desarrollo directivo.

Pant, P.N., \& Lachman, R. (1998). Value incongruity and strategic choice. Journal of Management Studies, 35, 195-212.

Pertegal M. A., Oliva A., Hernando A. (2010). Los Programas Escolares Como Promotores del Desarrollo Positivo Adolescente [Promoting Positive Youth Development Through School-Based Programmes]. Cult. Educ. 22, 53-66, 10.1174/113564010790935169 
Polo M., León B., Gómez T., Palacios V., \& Fajardo F. (2013). Estilos de Socialización en Víctimas de Acoso Escolar [Socialization styles victims of bullying]. Eur. J. Investig. Health Psychol. Educ. 3, 41-49, 10.1989/ejihpe.v3i1.22

Quested, E., \& Duda, J. L. (2009). Perceptions of the Motivational Climate, Need Satisfaction, and Indices of Well- and Ill-Being Among Hip Hop Dancers. Journal of Dance Medicine ef Science, 13, 1, 10 -19.

Rokeach M. (1968a). Beliefs, Atitudes and Values. San Francisco: Jossey Bass.

Rokeach M. (1968b). A theory of organization and change within value-attitude systems. J. Soc. Issues, 24, 13-33 10.1111/j.1540-4560.1968.tb01466.x

Rokeach, M., \& Ball-Rokeach, S.J. (1989). Stability and change in American values, 1969-1981. American Psychologist, 44, 775-784.

Ros M., Grad H. M., \& Martínez-Sánchez E. (1996). El Cambio de Valores Para la Mejora de las Estrategias de Aprendizaje and el Rendimiento Académico [Changing Values to Improve Learning Strategies and Academic Achievement]. Madrid: Informe CIDE.

Ryan, F. J. (1989). Participation in intercollegiate athletics: Affective outcomes. Journal of College Student Development, 30(2), 122-128.

Schwartz, S.H. (1992). Universals in the content and structure of values: Theoretical advances and empirical tests in 20 countries. In M. Zanna (Ed.), Advances in Experimental Social Psychology (Vol. 25, pp. 1-65). Orlando, FL: Academic Press.

Soltz, D. F. (1986)."Athletics and Academic Achievement: What Is the Relationship?" NASSP Bulletin, September 1986.

Steenkamp, J.B.E.M., ter Hofstede, F., \& Wedel, M. (1999). A cross-national investigation into the individual and national cultural antecedents of consumer innovativeness. Journal of Marketing, 63(2), 55-69.

Sutton J. \& Smith P. K. (1999). Social cognition and bullying: social inadequancy or skilled manipulation? Br. J. Dev. Psychol. 17, 435-450, 10.1348/026151099165384.

Thompson, R. (1986)."Improving the Academic Performance of Athletes." NASSP Bulletin, September 1986.

Wallace R., Pettit P., Scheffler S., \& Smith M. (2006). Reason and Value: Themes from the Moral Philosophy of Joseph Raz. New York, NY: Oxford University Press.

How to cite this article: L Paul, N Islam, M Hossain (2016), Interpersonal Values of Athletic and Non - Athletic Students of University of Chittagong, International Journal of Indian Psychology, Volume 3, Issue 3, No. 9, DIP: 18.01.171/20160303, ISBN: 978-1-365-13820-1 